\title{
APARELHO PARA A PESQUISA DA SENSIBILIDADE TERMICA
}

\author{
CARLOS GITAHY DE ALENCASTRO
}

Com frequência deparam-se os neurologistas com a necessidade de examinar a sensibilidade térmica de seus pacientes, fazendo-o mediante o emprego de tubos de ensaio contendo água quente e fria. Esta técnica é trabalhosa levando o neurologista a desistir da investigação. Por julgar útil a realização deste exame e também recohecendo o transtorno que acarreta sua realização pela metódica habitual, ocorreu-me montar um dispositivo prático.

O aparelhamento, que denominei Termo-sensor, é constituido de duas maças metálicas: uma, oca, alojando no seu interior uma resistência elétrica adequada e tendo, na extremidade de seu punho, dois pinos próprios para serem inseridos em tomada elétrica comum; a outra, de idênticas dimensões, não é provida nem da resistência elétrica nem dos pinos para inserção na tomada elétrica. A ligação do termo-sensor na tomada elétrica por 30 a 40 segundos, eleva sua temperatura a mais ou menos $50^{\circ} \mathrm{C}$. Assim, o especialista terá aparelhagem de fácil manejo, constituida de duas maças metálicas, uma quente a $50^{\circ} \mathrm{C}$ e a outra, fria, à temperatura ambiente, que serão encostadas nas superfícies em exame. A fotografia abaixo dá idéia do termo-sensor e também de seu tamanho.

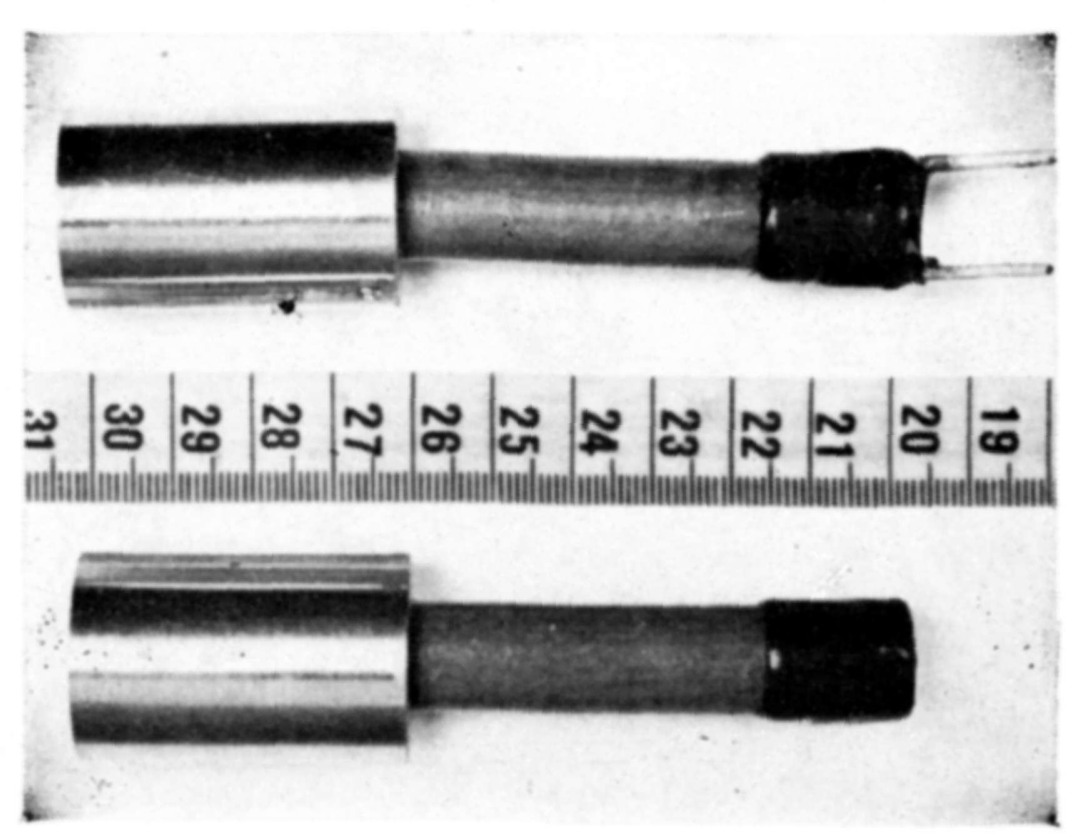

Dr. Carlos Gitahy de Alencastro - Av. Sete de Setembro 65, apto. 801 - 25600 Petropolis, RJ - Brasil. 